\title{
Innovative Model of Exercise Education in Environment Studies in University in China on the International View
}

\author{
Xiaoping Li ${ }^{1}$, Linna Feng ${ }^{2}$, Xu Zhang ${ }^{1}$, Lijun Wang ${ }^{1}$, Miao Ge ${ }^{1}$ \\ ${ }^{1}$ College of Tourism and Environment, Shaanxi Normal University, Xi'an, 710062, China \\ ${ }^{2}$ Department of Law and Foreign language, Shaanxi Police Professional College, Xi'an, 710054, China \\ lixiaoping@snnu.edu.cn
}

\begin{abstract}
Aims to solve the current problems of exercitation and practice education in environment science major at universities in China; based on the investigation of the characteristic and practicum of exercitation in environment science education at universities in USA, England and Japan. The integrated innovative model of "TWO MODEL, THREE ARRANGEMENTS, DIVERSIFICATION" was proposal to the environment science education in China. After application of this model in Shaanxi Normal University, the results displayed that the new proposal model will significantly take positive effect on and benefit on the college student professional training and ES education in universities in China.
\end{abstract}

Index Terms - International view; environment science; exercitation education; innovation model; higher education

\section{Introduction}

Environment science (ES) discipline is an interdisciplinary course program developed a multidimensional curriculum related with science, engineering and technologies as well as socio-economy and managerial aspects of environment. Founded in 1965, the Middlebury College Environmental Studies Program is the oldest undergraduate ES program in the United States. Up to 1990 s, about 300 colleges and universities had provided the environmental studies and ES program. According to the statistic data, there are more than 400 universities offered ES program now.

The exercitation is very important links in the ES education. It is not only a crosslink between the theory and practice, but also a key step to evaluate the abilities of analysis and solving environmental problems. Most environmental educators [1-3] have studied the exercitation curriculum and environmental professional training base; they also have proposed some suggestions for exercitation. However, in China, ES majors are usually distributed in the different department or college; it is no same standard to the exercitation. Each ES major in different university has the different exercitation project. This paper would aim to establish the new innovative model of exercitation education in ES major in universities based on the international view, and propose the "TWO MODEL, THREE ARRANGEMENTS, DIVERSIFICATION" pattern to reference to the exercitation education for the ES major in universities in China.

\section{Exercitation of ES major in university in the developed country}

American, England and Japan are the oldest country to offer the ES program in the world. Table 1 list the chosen exercitation courses offered in the environment studies in the high reputation universities from the three countries. From the Tab.1, it shows that the laboratory analysis and field work, scientific training and independent study, seminar and interdiscipline research are the main contents among the course curriculum. It is obvious that Emphasis on the interdiscipline education and abilities orientation is their characteristic.

TABLE 1 The exercitation courses offered in the representative university

\begin{tabular}{|l|l|}
\hline University & \multicolumn{1}{|c|}{ Exercitation courses } \\
\hline \multirow{3}{*}{$\begin{array}{l}\text { Middlebury } \\
\text { College }\end{array}$} & $\begin{array}{l}\text { Natural Science \& Environment, Environment Science } \\
\text { Practicum, Portrait of a Vermont Town, Vermont Waters, } \\
\text { Research Methods in Vermont Environmental Science, } \\
\text { Nature and Creativity, Environmental Studies Senior } \\
\text { Seminar, Independent Study, ES Senior Honors Work }\end{array}$ \\
\hline $\begin{array}{l}\text { University } \\
\text { of Reading }\end{array}$ & $\begin{array}{l}\text { Laboratory methods, Independent research project, Field } \\
\text { class (Environmental Science Field Class, Environmental } \\
\text { Science and Management field Course, Soil Science Field } \\
\text { Class, Earth Systems Field Class), Skills for } \\
\text { Environmental Scientists }\end{array}$ \\
\hline $\begin{array}{l}\text { University } \\
\text { of Tokyo }\end{array}$ & $\begin{array}{l}\text { Environmental measurement, Simulation methods, } \\
\text { Operations research, Earth system science, Industrial } \\
\text { Technologies, Food safety and risk analysis, Science, } \\
\text { technology and society, Specialized Seminar, Fieldwork, } \\
\text { International and Area Studies }\end{array}$ \\
\hline
\end{tabular}

(Source from the website: http://www.middlebury.edu/academics/es/courses; http://www.reading.ac.uk/Study/ug/EnvironmentalScienceBSc.aspx; http://peak.c.u-tokyo.ac.jp/our-courses/ESLibSen.html)

\section{The review and problem of exercitation education in environment studies in university in China}

ES is a new major in universities in China compared to others. However, the ES education has dramatically developed in the recent years. The ES education has formed its course system of lectures, laboratory, practice, field work and undergraduate thesis [1]. But the statistic data released from researchers [3] shows that $58.1 \%$ responders agree the ES courses rank ordinary level to meet the society demands comparing to other majors, while only 16.3 answers think the courses can fulfill society requirement. On the contrary, 23.3\% responders consider they can not satisfy the society demands. The courses exists two main problems comparing to ES 
curriculum in the developed country [4,5]. One is the course credits and percentages of field work are lower, anther is the shortage of independent studies in exercitation. The two problems result from none detail criteria and requirement as well as exercitation models in ES education in university. Nowadays, China has faced more serious environment problem, more qualified employee in ES would be needed. It is necessary to increase the course credits in field work and develop the basic exercitation model for ES education in university.

\section{The new innovative exercitation model in ES education in university}

According to the ES education and ES curriculum in developed country, aimed to the main problems in ES courses in China, the integrated innovative model of "TWO MODEL, THREE ARRANGEMENTS, DIVERSIFICATION" was proposal and listed in the Table 2.

TABLE 2 The integrated innovative model of "TWO MODEL, THREE ARRANGEMENTS, DIVERSIFICATION"

\begin{tabular}{|l|l|l|}
\hline \multicolumn{1}{|c|}{ Model } & Arrangement & \multicolumn{1}{|c|}{ Special Courses } \\
\hline \multirow{2}{*}{$\begin{array}{l}\text { Junior } \\
\text { exercitation } \\
\text { (I:basic) }\end{array}$} & $\begin{array}{l}\text { Laboratory } \\
\text { and seminar } \\
\text { biology, physics, mathematics, nature and } \\
\text { resource, ecology, engineering and } \\
\text { technology) Environmental Studies } \\
\text { Seminar, Research methods, Laboratory } \\
\text { methods and skills (soil, water, air, solid } \\
\text { waste, ecology, microbiology et al.) }\end{array}$ \\
\cline { 2 - 4 } & Field work & $\begin{array}{l}\text { Practicum and training (Waster water } \\
\text { treatment plant, power generate plant, } \\
\text { Environment monitor, Solid waste landfill } \\
\text { plant, Base of biodiversity et al.) }\end{array}$ \\
\hline $\begin{array}{l}\text { Senior } \\
\text { exercitation } \\
\text { (II:integrated) }\end{array}$ & $\begin{array}{l}\text { Independent } \\
\text { studies }\end{array}$ & $\begin{array}{l}\text { Specialized seminar, Independent research } \\
\text { project, thesis project, research assistant, } \\
\text { Senior honors research work }\end{array}$ \\
\hline
\end{tabular}

From the Table 2, two models are listed, one is junior exercitation including of laboratory and seminar, field work arrangements, and another is senior exercitation consist on the independent studies arrangement. Each arrangement should be composed by a series of special courses which will be chosen by college students from freshman to senior in ES major. The courses in model should be increased in the credits and percentages of exercitation education, and enhance on the interdiscipline skill and innovative abilities orientation.

\section{Case study}

Shaanxi Normal University (SNNU) is one of the key institutions of higher learning directly affiliated to Ministry of Education and it entered "211 Project University" in 2006. It is an important base of fostering teachers of higher education, middle school education and educational administrative cadres. It is regarded as "the cradle of teachers" in Northwest China. It offers Environmental Studies program for undergraduate and graduate in 2001. From then on, It has always continued on the research on the ES education and reform the course system in SNNU. Aims to enhance on the interdiscipline skill and innovative abilities orientation, and the application for the integrated innovative model of "TWO MODEL, THREE ARRANGEMENTS, DIVERSIFICATION" is summarized in the Table 3 . In the Table 3, the credits of exercitation have increased to the 23.5 and the percentage improves to the $14.7 \%$. The innovative model and its courses are successful to apply for the ES education. College students are pleased to choose the courses and their interdiscipline skill and innovative abilities have dramatically improved than before. The similar results are also found in the ES course reform research of $\mathrm{Xu}$ and Zhang $[6,7]$.

\section{Conclusion}

ES education in American, England and Japan is prominent in the world. The courses offered in their ES program would give a very good example to reference to ES major in China. The integrated innovative model of "TWO MODEL, THREE ARRANGEMENTS, DIVERSIFICATION" was proposal and it will benefit for enhancing on the interdiscipline education and abilities of college students. After application of this model in Shaanxi Normal University, the results displayed that the new proposal model will significantly take positive effect on and benefit on the ES education in universities in China.

\section{Acknowledgement}

Authors are grateful to the financial support from the project of "2012 key program of teaching reform of Shaanxi Normal University", "2010 program of youth teaching reform of Shaanxi Normal University" and "2010 program of environment science reform and development of Shaanxi Normal University".

\section{References}

[1] Q. Li, Y. Cao, Q. Zhu, W. Ding, L. Song, Y. Xie, "Study on the application-oriented system of practice teaching in environmental science", Journal of Chongqing University of Arts and Sciences ( Natural Science Edition), Vol. 30, No. 2, pp 75-80, April, 2011.

[2] J. Zhang, "Courses reform and practice teaching in professional exercitation based on the local environment", Journal of Shihezi University (Philosophy and Social Sciences), Vol. 25, pp 63-65, December, 2011.

[3] J. Zhang, "The basic research on the experiment courses in environment science major in higher education", Forum of teaching and education, No. 28, pp 124-126, October 2012.

[4] H. Zhang, X. Jia, "primary investigation of the environmental science and engineering experiment teaching reform", Chemical Engineering of Guangzhou, Vol. 38, No. 9, pp 195-196, 211, 2010.

[5] G. Zhang, D. Cui, N. Wang, "Reflection on the long-term operating pattern of extracurricular practice base o of environment science", Higher education of sciences, No. 89, pp 82-85, February, 2010.

[6] Z. Xu, H. Sun, "Reformation of curriculum and teaching method of speciality of environmental science", Journal of Anqing Teachers College (Natural Science Edition), Vol. 14, No. 1, pp 96-98, 61, February, 2008.

[7] H. Zhang, H. Liu, M. Chen, "Courses reform and practice in environment and resource major”, Kejiao Wenhui, No.9, pp 34-35, August, 2009. 
TABLE 3 The courses offered in ES in SNNU in the integrated innovative model of "TWO MODEL, THREE ARRANGEMENTS, DIVERSIFICATION"

\begin{tabular}{|c|c|c|c|}
\hline Model & Arrangement & Special Courses & Credits \\
\hline \multirow{19}{*}{$\begin{array}{l}\text { Junior } \\
\text { exercitation( I :basic) }\end{array}$} & \multirow{13}{*}{$\begin{array}{l}\text { Laboratory and } \\
\text { seminar }\end{array}$} & Organic chemistry experiment & 1 \\
\hline & & Inorganic and analytical chemistry experiment & 2 \\
\hline & & Microbiology environmental engineering experiment & 1 \\
\hline & & Environment chemistry experiment & 1 \\
\hline & & Environment monitoring experiment & 2 \\
\hline & & Waster water treatment engineering experiment & 2 \\
\hline & & Air pollution control engineering experiment & 1 \\
\hline & & Environmental measurement and simulation methods & 1 \\
\hline & & Environment engineering experiment & 1 \\
\hline & & Seminar in environment science and technology & 1 \\
\hline & & Environment analysis & 1 \\
\hline & & GIS application in ES & 1 \\
\hline & & Percentages in total credits & $9.4 \%$ \\
\hline & \multirow{6}{*}{ Field work } & $\begin{array}{l}\text { Integrated physical geography Practicum (National geology park of Cuihua } \\
\text { mountain) }\end{array}$ & \multirow{4}{*}{1.5} \\
\hline & & $\begin{array}{l}\text { Land desertification and integrated field work (Practicum in north of Shaanxi under } \\
\text { the project of college student summer excercitation) }\end{array}$ & \\
\hline & & $\begin{array}{l}\text { Integrated ecological field work of ecological engineering (Practicum in south of } \\
\text { Shaanxi under the project of college student summer excercitation) }\end{array}$ & \\
\hline & & Field work of environment soil (Portrait of Luochan in loess Plateau) & \\
\hline & & $\begin{array}{l}\text { Specialized field work and professional training (Xi'an waster water treatment plant, } \\
\text { Baoji power generate plant, Xi'an agency of Environment monitor, Xi'an Solid } \\
\text { waste landfill plant, Base of biodiversity in Qilin mountain) }\end{array}$ & 2 \\
\hline & & Percentages in total credits & $2.2 \%$ \\
\hline \multirow{5}{*}{$\begin{array}{l}\text { Senior } \\
\text { exercitation( II :integrated) }\end{array}$} & \multirow{5}{*}{ Independent studies } & Specialized seminar & 1 \\
\hline & & Research training & 1 \\
\hline & & Independent research & 1 \\
\hline & & Thesis project & 2 \\
\hline & & Percentages in total credits & $3.1 \%$ \\
\hline
\end{tabular}

